\title{
PENGARUH MODEL SCRAMBLE BERBASIS PUZZLE TERHADAP HASIL BELAJAR SISWA DI SEKOLAH DASAR
}

\author{
Adinda Tiara Kartika ${ }^{1}$, Didik Iswahyudi' \\ Arnelia Dwi Yasa ${ }^{3}$, Ninik Indawati ${ }^{4}$ \\ Universitas Kanjuruhan Malang \\ Atiara676@gmail.com ${ }^{1}$, didik@unikama.ac.id ${ }^{2}$, \\ arnelia@unikama.ac.id ${ }^{3}$, ninikberty@unikama.ac.id ${ }^{4}$
}

\begin{abstract}
Abstrak
Penelitian ini bertujuan untuk mengetahui pengaruh yang signifikan model scramble berbasis puzzle terhadap hasil belajar siswa di SDN Bandungrejosari 3 Kota Malang. Penelitian ini menggunakan pendekatan penelitian kuantitatif dengan rancangan penelitian Quasi Experimental Design dan desain penelitian Nonequivalent Control Group Design. Sampel yang digunakan dalam penelitian ini adalah seluruh populasi siswa kelas IV-A sebanyak 32 siswa sebagai kelas kontrol dan siswa kelas IV-B sebanyak 31 siswa sebagai kelas eksperimen. Instrumen yang digunakan dalam penelitian ini adalah tes.

Berdasarkan hasil uji hipotesis menggunakan uji t diperoleh nilai derajat kebebasan (df) $\mathrm{N}-2$ sebesar 61 . Hasil yang diperoleh untuk $\mathrm{t}_{\text {tabel }}$ sebesar 1,670 dan $\mathrm{t}_{\text {hitung }}$ sebesar 7,289. Nilai Sig. (2-tailed) sebesar 0,000. Karena nilai $t_{\text {hitung }}>t_{\text {tabel }}(7,289>1,670)$ dan signifikan 0,000<0,05 maka $\mathrm{H}_{\mathrm{a}}$ diterima dan $\mathrm{H}_{\mathrm{o}}$ ditolak. Sehingga dapat disimpulkan bahwa ada pengaruh model scramble berbasis puzzle terhadap hasil belajar siswa kelas IV di SDN Bandungrejosari 3 Kota Malang.
\end{abstract}

Kata Kunci: Model Scramble, Puzzle, Hasil Belajar

\begin{abstract}
This study aims to determine the significant effect of puzzle-based scramble models on student learning outcomes in Bandungrejosari 3 Elementary School Malang City. This study uses a quantitative research approach with a Quasi Experimental Design research design and Nonequivalent Control Group Design research design. The sample used in this study was all the population of students in class IV-A as many as 32 students as a control class and students of class $I V-B$ as many as 31 students as the experimental class. The instrument used in this study was a test.

Based on the results of hypothesis testing using the $t$ test, the value of the freedom of degrees (df) $N-2$ is 61. The results obtained for the table are 1.670 and tcount is 7.289. Sig value. (2-tailed) of 0,000. Because the value of $t_{\text {count }}>t_{\text {table }}(7,289>1,670)$ and significant $0,000<0,05$, $H_{a}$ is accepted and $H_{o}$ is rejected. So it can be concluded that there is an effect of puzzle-based scramble model on learning outcomes of fourth grade students in SDN Bandungrejosari 3 Malang City.
\end{abstract}

Keywords: Scramble Model, Puzzle, Learning Outcomes 


\section{PENDAHULUAN}

Pendidikan adalah salah satu upaya untuk membangun dan meningkatkan mutu sumber daya manusia yang disadari bahwa pendidikan merupakan sesuatu yang fundamental bagi setiap individu. Titik pusat yang harus dicapai dalam dunia pendidikan adalah tercapainya tujuan pendidikan. Kurikulum adalah ujung tombak bagi terlaksananya kegiatan pendidikan (Fadlillah, 2014). Kurikulum 2013 merupakan kurikulum yang mulai diterapkan pada tahun pelajaran 2013/2014. Tema pada Kurikulum 2013 adalah menghasilkan insan Indonesia yang produktif dan inovatif melalui penguatan sikap, pengetahuan, dan keterampilan. Untuk mewujudkan hal tersebut, guru dituntut secara profesional merancang pembelajaran yang efektif, bermakna dan menyenangkan (Mulyasa, 2016).

Proses pembelajaran di sekolah merupakan proses kependidikan yang terencana, terpadu, dan terkoordinasi secara sistematis dengan standar dan ukuran evaluasi yang jelas dan tegas. Salah satu komponen penting dalam pendidikan adalah proses pembelajaran yang tidak terlepas dari guru. Guru mempunyai peranan penting dalam menciptakan pembelajaran yang aktif dan efektif. Oleh karena itu, seorang guru harus mampu memilih model pembelajaran yang menarik dan dapat melibatkan siswa untuk berperan aktif dalam kegiatan pembelajaran, namun sampai saat ini guru masih menggunakan model pembelajaran konvensional dalam proses pembelajaran, sehingga membuat siswa menjadi kurang berminat dan terkesan pasif dalam kegiatan belajar mengajar. Dibutuhkan model pembelajaran yang tepat untuk meningkatkan konsentrasi dan keaktifan siswa, sehingga hasil belajar siswa tercapai dengan baik. Salah satunya yaitu model pembelajaran scramble.

Model pembelajaran merupakan pola atau alur yang digunakan dalam merencanakan pembelajaran di kelas maupun tutorial sebagai sebuah pedoman. Scramble ialah model pembelajaran yang meminta siswa untuk memilih alternatif jawaban yang tersedia dalam lembar soal dan lembar jawaban yang bertujuan untuk menemukan jawaban dan menyelesaikan permasalahan (Diani, Yuberti, \& Syafitri, 2016). Model pembelajaran scramble bertujuan untuk mengubah pola proses pembelajaran yang semula hanya berpusat kepada guru, akan diubah menjadi pola belajar yang berpusat pada siswa yang mengutamakan interaksi siswa dalam kelompok- kelompok kecil didalam proses pembelajaran (Ariyanto, 2016). Sistem bermain sambil belajar dalam model scramble ini perlu adanya pendukung dalam penerapannya, seperti puzzle. Puzzle adalah permainan tekateki menyusun gambar atau huruf yang diacak terlebih dahulu.

Penerapan permainan puzzle ini dapat menarik perhatian siswa, melatih nalar, ketekunan, tangkas, memperkuat ingatan, dan sabar dalam menyelesaikan sesuatu. Adapun penelitian terdahulu yang sejalan dengan penelitian ini antara lain penelitian yang dilakukan oleh (Rustam, 2016) menyatakan bahwa model Scrambel dengan pendekatan CTL berpengaruh terhadap hasil belajar siswa. (Dewi, Made Puspa; Putra, Andyana; Negara, 2013) Model pembelajaran scramble berbantuan media video berpengaruh terhadap hasil belajar siswa. (Winantara, 2019) Model pembelajaran Scramble efektif untuk meningkatkan hasil belajar IPA siswa Kelas IV SD. Perbedaan penelitian ini 
dengan penelitian terdahulu adalah model scramble yang digunakan berbantuan media puzzle, model pembelajaran digunakan pada pembelajaran tematik. Tujuan penelitian ini adalah untuk mengetahui pengaruh yang signifikan model scramble berbasis puzzle terhadap hasil belajar siswa kelas IV di SDN Bandungrejosari 3 Kota Malang.

\section{METODE PENELITIAN}

Penelitian ini dilakukan di SDN Bandungrejosari 3 Kota Malang. Pendekatan penelitian yang digunakan dalam penelitian ini adalah penelitian kuantitatif. Rancangan penelitian yang digunakan dalam penelitian ini adalah Quasi Experimental Design, desain penelitian Nonequivalent Control Group Design (Setyanto A E, 2006). Sampel penelitian siswa kelas IV-A sebanyak 32 siswa sebagai kelas kontrol dan siswa kelas IV-B sebanyak 31 siswa sebagai kelas eksperimen. Instrumen yang digunakan dalam penelitian ini adalah tes. Teknik pengumpulan data yang diperoleh dari hasil belajar siswa pada Tema 7 Subtema 1 Pembelajaran 1,2, dan 3 berbentuk soal obyektif sejumlah 20 soal pada awal (pretest) dan akhir (post-test) pembelajaran. Untuk melihat kualitas soal, maka dilakukan analisis butir soal yang meliputi uji validitas, uji reliabilitas, uji taraf kesukaran, dan uji daya pembeda(Emi Rofiah, Nonoh Siti Aminah, 2013).

Teknik analisis data dalam penelitian ini menggunakan uji prasyarat analisis meliputi uji normalitas dan uji homogenitas. Data yang normal dan homogen dilakukan agar dapat dianalisis dan menjadi syarat sebelum dilakukan uji hipotesis menggunakan uji t (Putrayasa, Syahruddin, \& Margunayasa, 2014). Apabila uji prasyarat analisis terpenuhi, maka langkah selanjutnya adalah melakukan uji hipotesis. Kriteria pengambilan keputusan hipotesis penelitian: $\left(\mathrm{H}_{\mathrm{a}}\right)$ "Ada pengaruh signifikan antara model scramble berbasis puzzle terhadap hasil belajar siswa kelas IV di SDN Bandungrejosari 3 Kota Malang". Sedangkan $\left(\mathrm{H}_{\mathrm{o}}\right)$ "Tidak ada pengaruh signifikan antara model scramble berbasis puzzle terhadap hasil belajar siswa kelas IV di SDN Bandungrejosari 3 Kota Malang”.

\section{HASIL DAN PEMBAHASAN}

Berdasarkan hasil analisis, hasil uji validitas dengan total 20 item soal dinyatakan valid. Hal ini dapat dilihat dari hasil analisis yang menunjukkan nilai $r_{\text {hitung }}>r_{\text {tabel }}$. Dimana besar nilai $r_{\text {tabel }}$ dengan nilai $N=20$ adalah 0,444 . Sedangkan uji realibilitas dengan menggunakan rumus Cronbach's Alpha, instrumen dinyatakan reliabel. Hal ini dapat dilihat dari hasil analisis yang menunjukkan nilai $\alpha=r_{\text {hitung }}(0,912)>r_{\text {tabel }}(0,444)$. Hasil uji taraf kesukaran soal menunjukkan bahwa 13 soal memiliki kriteria soal mudah dan 17 soal memiliki kriteria soal sedang. Pada uji daya pembeda diperoleh 2 soal baik sekali, 8 soal baik, dan 8 soal cukup.

Dari hasil uji normalitas dapat disimpulkan bahwa data berdistribusi normal. Hal ini dapat dilihat dari hasil analisis yang menunjukkan nilai signifikan $>0,05$. Hasil uji homogenitas dapat disimpulkan bahwa data nilai pre-test dan post-test adalah homogen. Secara keseluruhan data hasil penelitian dapat disajikan pada tabel 1 . 


\section{Tabel 1 Hasil Uji Hipotesis}

\begin{tabular}{|c|c|c|c|c|c|c|c|c|c|}
\hline \multicolumn{10}{|c|}{ Independent Samples Test } \\
\hline & $\begin{array}{l}\text { Lev } \\
\text { Te } \\
\text { Equ } \\
\text { Vari }\end{array}$ & $\begin{array}{l}\text { ene's } \\
\text { t for } \\
\text { lity of } \\
\text { ances }\end{array}$ & \multicolumn{7}{|c|}{ t-test for Equality of Means } \\
\hline & \multirow[b]{2}{*}{$\mathrm{F}$} & \multirow[b]{2}{*}{ Sig. } & \multirow[b]{2}{*}{$\mathrm{t}$} & \multirow[b]{2}{*}{ df } & \multirow{2}{*}{$\begin{array}{l}\text { Sig. } \\
(2- \\
\text { taile } \\
\text { d) }\end{array}$} & \multirow{2}{*}{$\begin{array}{l}\text { Mean } \\
\text { Differ } \\
\text { ence }\end{array}$} & \multirow{2}{*}{$\begin{array}{l}\text { Std. } \\
\text { Error } \\
\text { Differ } \\
\text { ence }\end{array}$} & \multicolumn{2}{|c|}{$\begin{array}{l}95 \% \text { Confidence } \\
\text { Interval of the } \\
\text { Difference }\end{array}$} \\
\hline & & & & & & & & Lower & Upper \\
\hline $\begin{array}{ll}\text { Hasil_Belajar Equal } \\
\text { Siswa_Post } & \text { variances } \\
\text { test } & \text { assumed }\end{array}$ & .079 & .779 & 7.289 & 61 & .000 & $\begin{array}{r}12.72 \\
2\end{array}$ & 1.745 & 9.232 & 16.212 \\
\hline $\begin{array}{l}\text { Equal } \\
\text { variances not } \\
\text { assumed }\end{array}$ & & & 7.289 & $\begin{array}{r}60.9 \\
38\end{array}$ & .000 & $\begin{array}{r}12.72 \\
2\end{array}$ & 1.745 & 9.232 & 16.212 \\
\hline
\end{tabular}

Berdasarkan tabel 1, diperoleh nilai derajat kebebasan (df) N-2 sebesar 61. Hasil yang diperoleh untuk $t_{\text {tabel }}$ sebesar 1,670 dan $t_{\text {hitung }}$ sebesar 7,289. Nilai Sig. (2-tailed) sebesar 0,000. Karena nilai $t_{\text {hitung }}>t_{\text {tabel }}(7,289>1,670)$ dan signifikan $0,000<0,05$ maka $\mathrm{H}_{\mathrm{a}}$ diterima dan $\mathrm{H}_{\mathrm{o}}$ ditolak. Sehingga dapat disimpulkan bahwa ada pengaruh signifikan antara model scramble berbasis puzzle terhadap hasil belajar siswa kelas IV di SDN Bandungrejosari 3 Kota Malang. Penelitian ini sejalan dengan penelitian yang dilakukan (Handayani \& Lestari, 2015) yang menyatakan bahwa model pembelajaran scrambel berpengaruh terhadap hasil belajar siswa. Model pembelajaran scrambel dapat meningkatkan aktivitas dan hasil belajar siswa(Tono, 2018).

\section{KESIMPULAN DAN SARAN}

Berdasarkan data hasil uji hipotesis menggunakan uji t disimpulkan bahwa ada pengaruh signifikan antara model scramble berbasis puzzle terhadap hasil belajar siswa kelas IV di SDN Bandungrejosari 3 Kota Malang. Saran bagi peneliti selanjutnya, dapat melakukan penelitian yang berkaitan dengan model scramble.

\section{DAFTAR RUJUKAN}

Ariyanto, M. (2016). e-ISSN: 2503-3530 p-ISSN 2406-8012 PENINGKATAN HASIL BELAJAR IPA MATERI KENAMPAKAN RUPA BUMI MENGGUNAKAN MODEL SCRAMBLE, 3(2), 134-140.

Dewi, Made Puspa; Putra, Andyana; Negara, O. I. G. A. (2013). Pengaruh Model Pembelajaran Pdeode Terhadap Hasil Belajar Ipa Siswa Kelas Iv Sd Di

Gugus V Kecamatan Seririt. E-Journal PGSD Universitas Pendidikan Ganesha Mimbar PGSD, 5(: 2), 1-10.

Diani, R., Yuberti, Y., \& Syafitri, S. (2016). Uji Effect Size Model Pembelajaran 
Scramble dengan Media Video Terhadap Hasil Belajar Fisika Peserta Didik Kelas X MAN 1 Pesisir Barat. Jurnal Ilmiah Pendidikan Fisika Al-Biruni, 5(2), 265. https://doi.org/10.24042/jpifalbiruni.v5i2.126

Emi Rofiah, Nonoh Siti Aminah, E. Y. E. (2013). Penyusunan Instrumen Tes Kemampuan Berpikir Tingkat Tinggi Fisika Pada Siswa SMP. Jurnal Pendidikan Fisika, 1(2), 17-22.

Fadlillah. (2014). Implementasi Kurikulum 2013 dalam Pembelajaran SD/MI, SMP/MTS, \& SMA/MA. Cet. 1. Yogyakarta: Ar-ruzz Media.

Handayani, S., \& Lestari, R. (2015). Pengaruh Model Pembelajaran Scramble Terhadap Hasil Belajar Siswa Kelas Vii Di Smp Negeri 2 Satu Atap, 1-5.

Mulyasa. (2016). Pengembangan dan Implementasi Kurikulum 2013. Bandung: Remaja Rosdakarya.

Putrayasa, I. M., Syahruddin, H., \& Margunayasa, I. G. (2014). Pengaruh Model Pembelajaran Discovery Learning Dan. Mimbar PGSD Universitas Pendidikan Ganesha, 2(1), 1-11.

Rustam, A. (2016). Improving the results of math learning through scramble cooperative model with the approach of contextual teaching improving the results of math learning through scramble cooperative model with the approach of contextual. Journal of Mathematics Education, 1(June 2017), 8. Retrieved from http://usnsj.com/index.php/JME

Setyanto A E. (2006). Memperkenalkan Kembali Metode Eksperimen dalam Kajian Komunikasi. Ilmu Komunikasi, 3(1), 37-48.

Tono, T. (2018). Peningkatan Aktivitas dan Hasil Belajar Siswa Kelas VI Mata Pelajaran PKN Materi Pokok Demokrasi Melalui Penerapan Model Pembelajaran Scramble Pada Siswa SD Negeri 1 Pakis Kecamatan Kradenan Tahun Pelajaran 2017/2018. Efektor, 5(1), 45. https://doi.org/10.29407/e.v5i1.11944

Winantara, I. W. D. (2019). Penerapan Model Pembelajaran Tps Untuk Meningkatkan Hasil Belajar Ipa Siswa Kelas V Sd No 1 Mengwitani. Journal of Education Action Research, 1(2), 148. https://doi.org/10.23887/jear.v1i2.12047 